\title{
POTENTIAL OF CHITOSAN FROM MUCOR ROUXXI UCP064 AS ALTERNATIVE NATURAL COMPOUND TO INHIBIT LISTERIA MONOCYTOGENES
}

\author{
Roberta A. Bento ${ }^{1}$, Tânia L.M. Stamford ${ }^{1}$, Galba M. de Campos-Takaki ${ }^{2}$, \\ Thayza C.M. Stamford ${ }^{3}$, Evandro L. de Souza ${ }^{4}$
}

\begin{abstract}
${ }^{1}$ Laboratório de Fermentação, Departamento de Nutrição, Centro de Ciências da Saúde, Universidade Federal de Pernambuco, Recife, PE, Brasil; ${ }^{2}$ Núcleo de Pesquisas em Ciências Ambientais, Departamento de Química, Universidade Católica de Pernambuco, Recife, PE, Brasil; ${ }^{3}$ Departamento de Fisiologia e Patologia, Centro de Ciências da Saúde, Universidade Federal da Paraíba, João Pessoa, PB, Brasil; ${ }^{4}$ Laboratório de Microbiologia de Alimentos, Departamento de Nutrição, Centro de Ciências da Saúde, Universidade Federal da Paraíba, João Pessoa, PB, Brasil
\end{abstract}

Submitted: August 07, 2008; Returned to authors for corrections: October 12, 2008; Approved: May 03, 2009.

\begin{abstract}
Listeria monocytogenes is widely distributed in nature and the infection listeriosis is recognized as a potential threat for human health because of its mortality rate. The objective of this study was to evaluate the growth profile and chitosan production by Mucor rouxxi UCP 064 grown in yam bean (Pachyrhizus erosus L. Urban) medium. It was also to assess the anti-L. monocytogenes efficacy of the obtained chitosan. Higher values of biomass of $M$. rouxxi $\left(16.9\right.$ g. $\left.\mathrm{L}^{-1}\right)$ and best yield of chitosan $\left(62 \mathrm{mg} \cdot \mathrm{g}^{-1}\right)$ were found after $48 \mathrm{~h}$ of cultivation. Residual glucose and nitrogen in the growth media were 4.1 and 0.02 g. $\mathrm{L}^{-1}$ after 96 h, respectively. Obtained chitosan presented $85 \%$ of degree of deacetylation and $2.60 \times 10^{4}$ g. $\mathrm{mol}^{-1}$ of viscosimetric molecular weight. Minimum Inhibitory Concentration (MIC) and Minimum Bactericidal Concentration (MBC) values of chitosan against L. monocytogenes ATCC 7644 were, respectively, 2.5 and $5.0 \mathrm{mg} \cdot \mathrm{mL}^{-1}$. At 2.5 and $5.0 \mathrm{mg} \cdot \mathrm{mL}^{-1}$ chitosan caused cidal effect in a maximum time of $4 \mathrm{~h}$. Bacterial count below $2 \log$ cfu. $\mathrm{mL}^{-1}$ were found from $2 \mathrm{~h}$ onwards and no recovery in bacterial growth was noted in the remainder period. These results show the biotechnological potential of yam bean medium for chitosan production by Mucor rouxxi and support the possible rational use of chitosan from fungi as natural antimicrobial to control L. monocytogenes.
\end{abstract}

Key words: chitosan, Mucor rouxxi, antilisterial property, biocontrol.

\footnotetext{
*Corresponding Author. Mailing address: Laboratory of Food Microbiology, Department of Nutrition, Health Science Center, Federal University of Paraíba, João Pessoa, Brazil.; E-mail: evandroleitesouza@ccs.ufpb.br
} 


\section{INTRODUCTION}

Listeria monocytogenes is widely distributed in nature and has been frequently isolated from a range of sources such as soil, decaying vegetables, vegetal matter, silage, sewage, animal feed, fresh and processed meats, dairy products, slaughter-house waste and food processing plants $(3,22)$. Listeriosis is recognized as a potential threat for human health because of its high mortality rate, particularly in immune-suppressed patients, neonates, children, pregnant woman and elderly (16).

Since the majority of human listeriosis is caused by the consumption of contaminated food, alternative anti- $L$. monocytogenes strategies to control this pathogen in foods are of particular interest. Particularly, the increased demand for safe and natural foods has provoked researchers to investigate the antimicrobial efficacy of many natural compounds against some food-related pathogen microorganisms (13). Concern over the negative consumer perception to chemical preservatives prompts an increased interest in the antimicrobial properties of chitosan to be applied in food conservation $(4,8)$.

Chitosan is a cationic amino polysaccharide, common constituent of fungal cell walls, particularly the class of Zygomycetes, essentially composed of $\beta$ - 1,4 Dglucosamine linked to $\mathrm{N}$-acetyl-D-glucosamine residues. This polymer is traditionally obtained by chemically deacetylation of crustacean chitin $(5,15)$. Antimicrobial efficacy of chitosan depends on its molecular weight and methods used to convert chitin to chitosan because it could affect the characteristics of deacetylation and distribution of acetyl groups, chain length, and the structure conformation of chitosan molecule (4).

In order to obtain chitosan of greater quality, filamentous fungi have been known as attractive source for industrial applications $(1,2)$ since it can be carried out by a simple process of extraction resulting in the obtainment of chitosan with no amount of proteins involved in human allergic reactions to shellfish (24). This study aimed to evaluate the chitosan production by Mucor rouxxi UCP 064 growing in the alternative yam bean (Pachyrhizus erosus L. Urban) media, and also to verify the efficacy of the obtained chitosan as anti-L. monocytogenes compound.

\section{MATERIAL AND METHODS}

\section{Microorganism and culture conditions}

Mucor rouxxi UCP 064 (Microorganism Culture Collection, Catholic University of Pernambuco, Recife, Brazil) isolated from mangrove sediment (Rio Formoso, Pernambuco, Brazil) was assayed for chitosan production. The strain was kept at Potato Dextrose Agar slants at $4{ }^{\circ} \mathrm{C}$. For chitosan production, spores were harvest of 7 days-old cultures grown on Potato Dextrose agar Petri dishes by adding sterile $\mathrm{NaCl}\left(0.85 \mathrm{~g} .100 \mathrm{~mL}^{-1}\right)$ on the medium growth followed for gentle shaking during $30 \mathrm{~s}$. Spores suspension was adjusted with sterile $\mathrm{NaCl}\left(0.85\right.$ g. $100 \mathrm{~mL}^{-}$ ${ }^{1)}$ to have approximately $10^{8}$ spores.mL $L^{-1}$ using a hemocytometer.

Listeria monocytogenes ATCC 7644 (Laboratory of Food Microbiology, Department of Nutrition, Federal University of Pernambuco, Recife, Brazil) was assayed as revealed strain. Stock culture was kept on Muller-Hinton agar slants at $4{ }^{\circ} \mathrm{C}$. Inocula used in antimicrobial assays were obtained from overnight cultures grown on BHI broth at $37{ }^{\circ} \mathrm{C}$. After incubation, bacterial cells were separated from the growth medium by centrifugation (10000 rpm, 10 min), washed three times in buffered $\mathrm{KCl}(0.05 \mathrm{M} \mathrm{KCl}, 1$ $\mathrm{mM} \mathrm{KH} \mathrm{KH}_{4}, 1 \mathrm{Mm} \mathrm{CaCl}_{2}, 0.1 \mathrm{Mm} \mathrm{MgCl}_{2}, \mathrm{pH}$ 6.0) and resuspended in buffered $\mathrm{KCl}$. Cell suspension was adjusted for a optical density at $600 \mathrm{~nm}$ of 1.5 providing a bacterial inocula of approximately $1.0 \times 10^{8} \mathrm{cfu} \cdot \mathrm{mL}^{-1}$. 


\section{Chitosan production}

The production of chitosan was carried out by submerse cultivation in yam bean (Pachyrhizus erosus L. Urban) medium (protein 8.72; starch 40.9; glucose 11.4 g. $\mathrm{L}^{-1} ; \mathrm{pH}$ 7.0) prepared according to Stamford et al. (24). For this, $10 \mathrm{~mL}$ of $M$. rouxxi UCP 064 spores suspension ( $c$ a $10^{8}$ spores. $\mathrm{mL}^{-1}$ ) was inoculated in Erlenmeyer flasks of $1000 \mathrm{~mL}$ containing $290 \mathrm{~mL}$ of growth medium, followed for incubation at $28^{\circ} \mathrm{C}$ in an orbital shaker (150 rpm) for 96 h. Mycelia were harvested, washed twice in distilled water and submitted to lyophilization. Afterward, the obtained mass was maintained in a vacuum dissecator until constant weight.

During the cultivation aliquots were collected every 24 $\mathrm{h}$ for determination of biomass, chitosan production, $\mathrm{pH}$, glucose and total nitrogen. Measure of biomass (g) was performed by a gravimetric procedure; glucose consumption (g. $\mathrm{L}^{-1}$ ) was determined by an enzymatic colorimetric method (Labtest ${ }^{\circledR}$ Kit - Glucose oxidase); nitrogen consumption (g. $\left.\mathrm{L}^{-1}\right)$ was found by a colorimetric method (Labtest ${ }^{\circledR}$ Kit for protein); $\mathrm{pH}$ was measured using a potentiometer (Digital Pontentiometer Quimis Mod. 400 A). All assays were performed twice.

\section{Chitosan extraction}

The chitosan extraction involved deproteination with $2 \%(\mathrm{w} / \mathrm{v})$ sodium hydroxide solution $\left(30: 1 \mathrm{v} / \mathrm{w}, 90^{\circ} \mathrm{C}, 2 \mathrm{~h}\right)$, separation of alkali-insoluble fraction (AIF) by centrifugation (4000 rpm, $15 \mathrm{~min}$ ), extraction of chitosan from AIF under reflux $\left(10 \% \mathrm{v} / \mathrm{v}\right.$ acetic acid $40: 1 \mathrm{v} / \mathrm{w}, 60^{\circ} \mathrm{C}$, $6 \mathrm{~h}$ ), separation of crude chitin by centrifugation (4000 rpm, $15 \mathrm{~min}$ ) and precipitation of chitosan from the extract at $\mathrm{pH}$ 9.0 (adjusted with a $4 \mathrm{M} \mathrm{NaOH}$ solution). Crude chitin and chitosan were washed with distilled water, ethanol and acetone and air-dried at $20^{\circ} \mathrm{C}(10)$.
Chitosan was assessed in a range of $160-0.06 \mathrm{mg} \cdot \mathrm{mL}^{-1}$ for anti-L. monocytogenes effect. Chitosan solutions were prepared in acetic acid (1\%) and adjusted to $\mathrm{pH} 5.8$ using $\mathrm{NaOH}$ or $\mathrm{HCl}(21)$.

\section{Determination of deacetylation degree (DD) and molecular weight $\left(\mathrm{MW}_{\mathrm{v}}\right)$ of chitosan \\ DD of chitosan was determined using infrared} spectroscopy, and an absorbance ratio (A \%) was calculated as follow: (9A1655/A3450) $\mathrm{x} 100 / 1.3$. For this, two milligrams of chitosan overnight dried at $60^{\circ} \mathrm{C}$ were mixed with $100 \mathrm{mg}$ of $\mathrm{KBr}$ to provide $0.5 \mathrm{~mm}$ thick disks. The disks were dried for $24 \mathrm{~h}$ at $110^{\circ} \mathrm{C}$ under reduced pressure. Infrared spectroscopy was recorded using a Bruker 66 Spectrometer and $100 \mathrm{mg} \mathrm{KBr}$ disks for reference. Intensity of maximum absorbance bands were found by the baseline method (19).

$\mathrm{MW}_{\mathrm{v}}$ of chitosan was found by viscosity (20). The viscosity of chitosan was determined using an AVS-350 viscosimeter (Schott-Geräte), type/capillary: CannonFenske $\mathrm{d}_{\text {inside }}=1.01 \mathrm{~mm}$, at $25^{\circ} \mathrm{C}$. After getting the intrinsic viscosity from tables $\mathrm{K}$ and $\mathrm{a}$, were obtained for HAc/NaAc. $K=0.076, a=0.76$. The flow time was determined in seconds. Mark-Houwinks equation was used to find the average viscosimetric molecular weight in g. $\mathrm{mol}^{-1}$.

\footnotetext{
Determination of Minimum Inhibitory Concentration MIC and Minimum Bactericidal Concentration - MBC

MIC and MFC of chitosan was found by macrodilution in broth. $5 \mathrm{~mL}$ of double strength BHI broth was inoculated with $1 \mathrm{~mL}$ of the bacterial inocula $\left(\mathrm{ca} 10^{8} \mathrm{cfu} \cdot \mathrm{mL}^{-1}\right)$. After that, $4 \mathrm{~mL}$ of the chitosan solution at different concentrations $(160,80,40,20,10,5,2.5,1.25,0.06,0.03$ $\mathrm{mg} \cdot \mathrm{mL}^{-1}$ ) was added and followed by shaking for $30 \mathrm{~s}$. The
} 
system was statically incubated for $24 \mathrm{~h}$ at $35^{\circ} \mathrm{C}$. MIC was defined as the lowest concentration required to completely preventing visible bacterial growth. An aliquot $(100 \mu \mathrm{L})$ of the tubes with no visible bacterial growth was subcultured on sterile Muller-Hinton agar at $35^{\circ} \mathrm{C}$ for $48 \mathrm{~h}$ to determine if the inhibition was reversible or permanent. MBC was defined as the lowest concentration which no growth was noted on Muller-Hinton agar. Control flasks without chitosan were tested in the same way.

\section{Time-kill assay}

For analyzing 96-h time-kill curves chitosan was assayed at 5.0 and $2.5 \mathrm{mg} \cdot \mathrm{mL}^{-1}$. For this, $5 \mathrm{~mL}$ of double strength BHI broth was inoculated with $1 \mathrm{~mL}$ of the bacterium suspension (c.a. $10^{6}$ cfu. $\mathrm{mL}^{-1}$ ). After that, $4 \mathrm{~mL}$ of chitosan was added to obtain the final proper concentrations, and the culture statically incubated at $37^{\circ} \mathrm{C}$. Aliquots $(100 \mu \mathrm{L})$ were taken at $0,1,2,4,8,12,24,48,72$ and $96 \mathrm{~h}$, serially diluted in sterile peptone water $(0.1 \%$ $\mathrm{w} / \mathrm{v})$ and spread-plated onto sterile Muller-Hinton agar. After $48 \mathrm{~h}$ of incubation at $37{ }^{\circ} \mathrm{C}$, colonies were counted and the results were expressed in log of count forming unit per $\mathrm{mL}$ (cfu. $\mathrm{mL}^{-1}$ ). Control flasks without chitosan were tested in the same way.

\section{Statistical analysis}

The data of kill-times were analyzed for significance $(\mathrm{p}<0.01)$ by the Tukey test using STATISTICA program version 6.0 of Statsolt Inc., USA. All experiments were carried out in triplicate and the results are expressed as mean of the parallel assays.

\section{RESULTS AND DISCUSSION}

Results of biomass, chitosan production, glucose and nitrogen consumption of Mucor rouxxi UCP 064 growing in yam bean medium at $28{ }^{\circ} \mathrm{C}$ are showed in Figure 1. Biomass production increased rapidly within $48 \mathrm{~h}$, and reached the highest value (16.9 g. $\left.\mathrm{L}^{-1}\right)$ after $72 \mathrm{~h}$ of cultivation. Synowiecki and Al-Khatteb (25) found highest amount of biomass $\left(4\right.$ g.L $\left.\mathrm{L}^{-1}\right)$ of Mucor rouxii growing in yeast extract and glucose $2 \%$ medium after $48 \mathrm{~h}$. Residual glucose and nitrogen in the growth medium were 4.1 and 0.02 g. $\mathrm{L}^{-1}$, respectively. Similar results were reported by Franco et al. (10) and Stamford et al. (24).

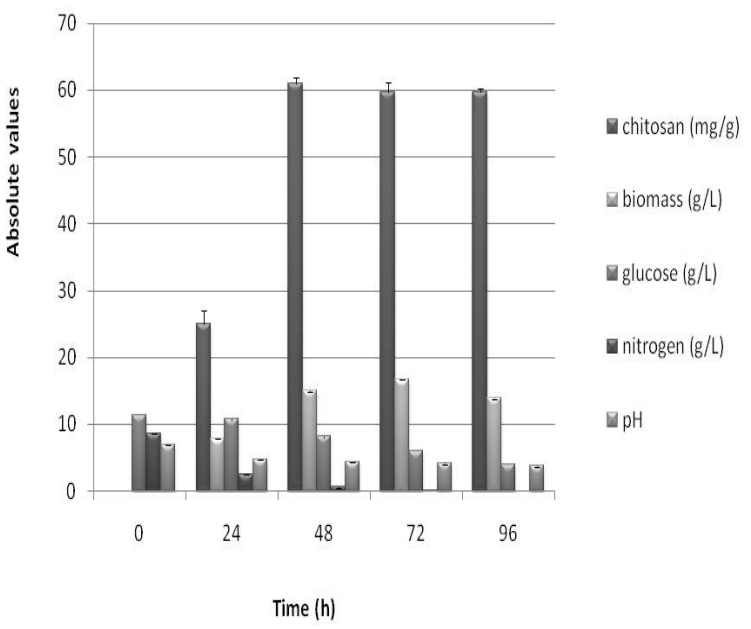

Figure 1. Curve of growth, chitosan production, $\mathrm{pH}$, glucose and nitrogen consumption of Mucor rouxxi UCP 064 grown in yam bean medium at $28^{\circ} \mathrm{C}, 150 \mathrm{rpm}$, during $96 \mathrm{~h}$ of cultivation.

$\mathrm{pH}$ of the medium dropped to 5-4 in the first $48 \mathrm{~h}$ during the growth of $M$. rouxxi, and stayed near to 4 for the remainder period. $\mathrm{pH}$ values decreased during the exponential growth phase, probably, because the high amount of glucose and starch in yam bean medium resulting in production of pyruvic acid. Best yield of chitosan (mg per gram of dry mycelia biomass) was obtained with 48 hours of culture $\left(62 \mathrm{mg} \cdot \mathrm{g}^{-1}\right)$. This result is in agreement with Stamford et al. (24) investigating the 
production of chitosan from $C$. elegans in yam bean medium, where noted best yield of chitosan $\left(66 \mathrm{mg} \cdot \mathrm{g}^{-1}\right)$ with 48 hours of cultivation.

Chitosan obtained from $M$. rouxxi grown on yam bean medium presented $85 \% \mathrm{DD}$ and $2.60 \times 10^{4} \mathrm{~g} \cdot \mathrm{mol}^{-1}$ of $\mathrm{MW}_{\mathrm{v}}$. In general, DD of chitosan from fungi is in a range of 80 to $90 \%(5,11,17) .2 .60 \times 10^{4}$ g. $\mathrm{mol}^{-1}$ of $\mathrm{MW}_{\mathrm{v}}$ characterizes the tested chitosan as having low molecular weight. Chitosan of low molecular weight presents reduced tensile strength resulting in elongation of its molecule and increased permeability in for bacterial membrane (17).

MIC and MBC values of chitosan from $M$. rouxxi UCP 064 grown in yam bean medium against $L$. monocytogenes ATCC 7644 were, respectively, 2.5 and 5.0 mg. $\mathrm{mL}^{-1}$. Previous studies reported on the antimicrobial property of a variety of chitosan toward some food-related microorganisms, including the bacteria Staphylococcus aureus, Escherichia coli (26), Salmonella tiphymurium (6), and the fungi Fusarium and Alternaria (7).

Kanatt et al. (12) states that most studies has noted MIC values of chitosan in a range of $0.1-10 \mathrm{mg} \cdot \mathrm{mL}^{-1}$ against food-related microorganisms. Even the MIC and MBC values of chitosan are regarded high in comparison to other alternative antimicrobial compounds (e.g. essential oils, phenolics, bacteriocins), broad spectrum of antimicrobial activity and low toxicity to mammalian cells makes it a promising antimicrobial compound to be applied in foods (18).

Kill-curves of L. monocytogenes ATCC 7644 when treated with chitosan from M. rouxxi UCP 064 along $96 \mathrm{~h}$ is showed in Figure 2. At $2.5 \mathrm{mg} \cdot \mathrm{mL}^{-1}$ chitosan caused cidal effect ( $\geq 3 \log _{10}$ reduction in viable cells, i.e., $\geq 99.9 \%$ kill rate) after $4 \mathrm{~h}$, compared to $2 \mathrm{~h}$ for concentration 5.0 mg. $\mathrm{mL}^{-1}$. Values smaller than $2 \log$ cfu. $\mathrm{mL}^{-1}$ were found at the remainder periods with no recovery in bacterial growth.
Chitosan at 2.5 and $5 \mathrm{mg} \cdot \mathrm{mL}^{-1}$ caused significant decrease $(p<0.01)$ of the bacterial count in comparison to the control assay. Results from the kill-curves demonstrated a clear concentration and time-dependent inhibitory effect of the assayed chitosan.

Although some researchers have reported antimicrobial property of commercial chitosan there has been few data about the antimicrobial potential of chitosan from fungi. Fai (9) found MIC values of $1.25 \mathrm{mg} \cdot \mathrm{mL}^{-1}$ for chitosan from Mucor circinelloides UCP $050\left(\mathrm{MW}_{\mathrm{v}} 2.7 \times 10^{4} \mathrm{~g} \cdot \mathrm{mol}^{-1}\right.$, DD $83 \%$ ) against L. monocytogenes, Staphylococcus aureus, E. coli, Salmonella enterica and Yersinia enterocolitica, while MBC were two or four-fold higher. Stamford (23) reported MIC values of chitosan from Cunninghamela elegans UCP $542\left(\mathrm{MW}_{\mathrm{v}} 4.02 \times 10^{4}\right.$ g. $\mathrm{mol}^{-1}$, DD $\left.85 \%\right)$ of $1.25 \mathrm{mg} \cdot \mathrm{mL}^{-1}$ against Streptococcus mutans, S. sanguis, S. mitis and $S$. oralis.

Antimicrobial activity of chitosan is believed to originate from its polycationic nature, being hypothesized to be mediated by the electrostatic forces between the protonated amino group $\left(\mathrm{NH}_{2}\right)$ in chitosan and the negative residues at cell surfaces (4). The cidal effect of chitosan toward L. monocytogenes is probably caused by the electrostatic interaction between $\mathrm{NH}_{3}{ }^{+}$groups of chitosan and the negatively charged phosphoryl groups of phospholipid components of the cell membrane (14).

The results obtained in this study show the yam been medium as suitable media for production of chitosan by Mucor rouxxi. Moreover, the chitosan studied here presented interesting anti-L.monocytogenes property in synthetic media. Chitosan from fungi could become a promising compound for controlling L. monocytogenes in human and/or veterinary medicine and in foods. Particularly, the results of this study encourage further researches in our laboratory about the antimicrobial effect of the assayed chitosan toward other 
food-related pathogens in synthetic media and food matrix.

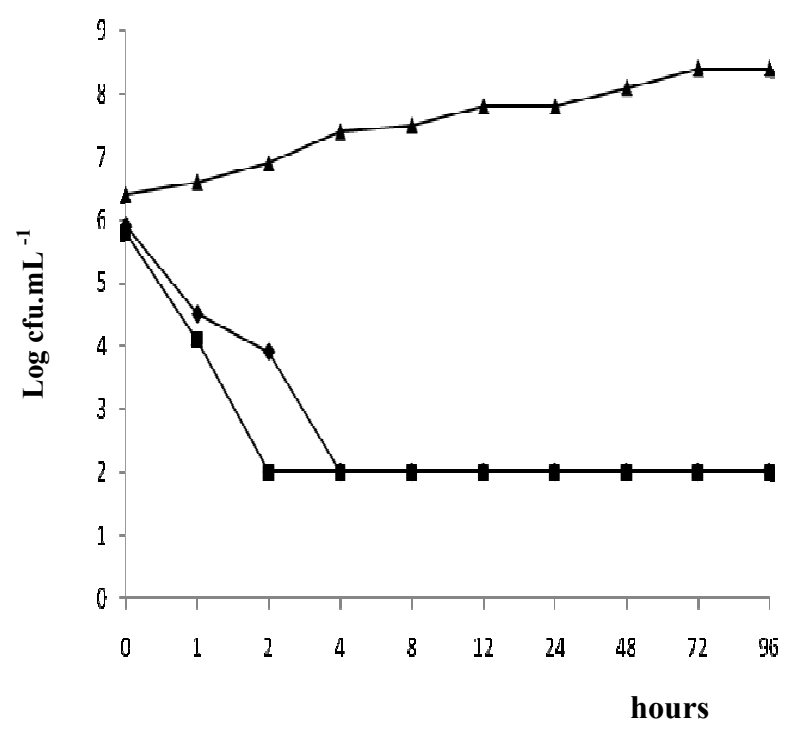

Figure 2. Survivors curves for L. monocytogenes ATCC 7644 in Brain Heart Infusion Broth at $35^{\circ} \mathrm{C}$ during $96 \mathrm{~h}$ as a function of chitosan concentration: $(\boldsymbol{\Delta})$ : control $\left(0 \mu \mathrm{L} \cdot \mathrm{mL}^{-1}\right)$; $(\diamond)$ : chitosan CIM (2.5 $\left.\mu \mathrm{g} \cdot \mathrm{mL}^{-1}\right)$; (®): chitosan CBM (5.0 $\left.\mu \mathrm{g} \cdot \mathrm{mL}^{-1}\right)$. The detection limit for viable cells was $2 \log$ cfu. $\mathrm{mL}^{-1}$. Where no cells were recovered, the detection limit is indicated.

\section{RESUMO}

\section{Potencial de quitosana de Mucor rouxxi UCP 064 como componente alternativo para inibir Listeria monocytogenes}

Listeria monocytogenes apresenta-se como um microrganismo amplamente distribuído na natureza, sendo que a infecção listeriose é reconhecida como uma potencial ameaça a saúde humana devido a sua taxa de mortalidade. O objetivo deste estudo foi avaliar o perfil de crescimento e de produção de quitosana por Mucor rouxxi UCP 064 cultivado em meio jacatupé (Pachyrhizus erosus L. Urban), bem como avaliar a eficácia anti-L. monocytogenes da quitosana produzida com vistas a uma possível aplicação em alimentos. Os mais elevados valores de biomassa de $M$. rouxxi $\left(16,9\right.$ g. $\left.\mathrm{L}^{-1}\right)$ e o maior rendimento na produção de quitosana (62 mg. $\mathrm{g}^{-1}$ ) foram encontrados após 48 horas de cultivo. As quantidades residuais de glicose e nitrogênio no meio de crescimento após 96 horas foram 4,1 e 0,02 g. $\mathrm{L}^{-1}$, respectivamente. A quitosana obtida apresentou grau de deacetilação de $85 \%$ e peso molecular de $2,6 \times 10^{4}$ g. $\mathrm{mol}^{-1}$. Os valores da Concentração Inibitória Mínima (CIM) e Concentração Bactericida Mínima (CBM) da quitosana sobre L. monocytogenes ATCC 7664 foram, respectivamente, 2,5 e $5,0 \mathrm{mg} \cdot \mathrm{mL}^{-1}$. Nas concentrações de 2,5 e 5,0 mg.mL $\mathrm{mL}^{-1}$ a quitosana fúngica causou um efeito bactericida em um tempo máximo de 4 horas. Valores de contagens menores que $2 \log$ ufc. $\mathrm{mL}^{-1}$ foram encontrados a partir de 2 horas, sendo que nenhuma recuperação no crescimento bacteriano foi encontrado até 96 horas. Estes resultados mostram o potencial biotecnológico do meio jacatupé para produção de quitosana por Mucor rouxxi, bem como suportam o possível uso racional de quitosana fúngica como antimicrobiano natural para controlar o crescimento de L. monocytogenes.

Palavras-chave: quitosana, Mucor rouxxi, efeito antiListeria, biocontrole.

\section{REFERENCES}

1. Amorim, R.V.S.; Ledingham, W.M.; Fuskushima, K.; Campos-Takaki, G.M. (2005). Screening of chitin deacetylase from Mucor strains (Zygomycetes) and its relationships to cell growth rate. J. Ind. Microbiol. Biotechnol., 32, 19-23.

2. Amorim, R.V.S.; Pedrosa, R.P.; Kazutaka, F.; Martínez, C.R.; Ledingham, W.M.; Campos-Takaki, G.M. (2006). Alternative carbon sources from sugar cane process for submerged cultivation of Cunninghamella bertholletiae to produce chitosan. Food Technol. 
3. Azevedo, I.; Regalo, M.; Mena, C.; Almeida, G.; Carneiro, L.; Teixeira, P.; Hogg, T.; Gibbs, P. (2005). Incidence of Listeria spp. in domestic refrigerators in Portugal. Food Cont., 16, 121-124.

4. Beverlya, R.L.; Janes, M.E.; Prinyawiwatkula, W.; No, H.K. (2008). Edible chitosan films on ready-to-eat roast beef for the control of Listeria monocytogenes. Food Microbiol. 25, 534-537.

5. Chatterjee, S.; Adhya, M.; Guah, A.K.; Chatterjee, B.P. (2005). Chitosan from Mucor rouxii: production and physico-chemical characterization. Process Biochem., 40, 395-400.

6. $\quad$ Chung, Y.C.; Su, Y.A.; Chen, C.C.; Jia, G.; Wang, H.L.; Wu, J.C.G.; Lin, J.G. (2004). Relationship between antibacterial activity of chitosan and surface characteristics of cell wall. Acta Pharmacolgica Sinica, 25, 932-936.

7. Costa e Silva, H.S.R.; Santos, K.S.C.R.; Ferreira, E.I. (2006). Quitosana: derivados hidrossolúveis, aplicações farmacêuticas e avanços. Quim. Nova, 29, 776-785.

8. Devlieghere, F.; Debevere, A.V. (2004). Chitosan: antimicrobial activity, interactions with food components and applicability as a coating on fruits and vegetables. Food Microbiol., 21, 703-714.

9. Fai, A.E.C. (2008). Potencial do efeito antibacteriano de quitosana extraída de Mucor circinelloides UCP 050: uma abordagem para uso em sistemas de conservação de alimentos. Msc dissertation. Federal University of Pernambuco, Recife, Brazil. 943p.

10. Franco, L.O.; Maia, R.C.G.; Porto, A.L.; Messias, A.C.; Fuskushima, K.; Campos-Takaki, G.M. (2004). Heavy metal biosorption by chitin and chitosan isolated from Cunninghamella elegans (IFM 46109). Braz. J. Microbiol., 35, 243-247.

11. Franco, L.O.; Stamford, T.C.M.; Stamford, N.P.; Campos-Takaki, G.M. (2005). Cunningamella elegans (IFM 46109) como fonte de quitina e quitosana. Rev. Analyt., 14, 40-44.

12. Kanatt, S.; Chander, R.; Sharma, A. (2008). Chitosan and mint mixture: a new perspective for meat and meat products. Food Chem., $107,845-852$.

13. Lin, Y.T.; Labbe, R.G.; Shetty, K. (2005). Inhibition of Vibrio parahaemolyticus in seadfood systems using oregano and cramberry phytochemicals synergies and lactic acid. Innovat. Food Sci. Technol., 6, 453-458.
14. Liu, J.; Zhang, J.; Xia, W. (2004). Hypocholesterolaemic effects of different chitosan samples in vitro and in vivo. Food Chem., 107, 419-425.

15. No, H.K.; Park, N.Y.; Lee, S.H.; Meyers, S.P. (2002). Antibacterial activity of chitosan and chitosan oligomers with different molecular weights. Int. J. Food Microbiol., 74, 65-72.

16. Peccio, A.; Autio, T.; Korkeala, H.; Rosmini, R.; Trevisani, M (2003). Listeria monocytogenes occurrence and characterization in meat producing plants. Let. Appl. Microbiol., 37, 234-238

17. Pochanavanich, P.; Suntornsuk, W. (2002). Fungal chitosan production and its characterization. Lett. Appl. Microbiol., 35, 17-21.

18. Rhoades, J.; Roller, S. (2000). Antimicrobial actions of degraded and native chitosan against spoilage organisms in laboratory media and foods. Appl. Environ. Microbiol., 66, 80-86.

19. Roberts, G.A.F. (1992). Chitin Chemistry. London, McMillan Press.

20. Santos, J.E.; Soares, J.P.; Dockal, E.R.; Campana Filho, S.P.; Cavalheiro, E.T.G. (2003). Caracterização de quitosanas comerciais de diferentes origens. Polímeros: Ciência e Tecnologia, 13, 242-249.

21. Shigemasa, Y.; Minami, S. (1996). Application of chitin and chitosan for biomaterials. Biotechnol. Gen. Eng. Rev., 17: 413-420.

22. Souza, V.M.; Franceschini, S.A.; Martinez, R.C.R.; Ratti, R.P.; de Martinis, E.C.P. (2008). Survey of Listeria spp. in matched clinical, food and refrigerator samples at home level in Brazil. Food Cont., 19, $1011-1013$

23. Stamford, T.C. (2006). Produção, caracterização e atuação anticariogênica de quitosana extraída de Cunninghamella elegans UCP 542. PhD thesis. Federal University of Pernambuco, Recife, Brazil. 143p.

24. Stamford, T.C.M.; Stamford, T.L.M.; Stamford, N.P.; Barros Neto, B.B.; Campos-Takaki, G.M. (2007). Growth of Cunninghamella elegans UCP 542 and production of chitin and chitosan using yam bean medium. Electron. J. Bitechnol., 10, 61-68.

25. Synowiecki, J.; Al-Khatteb, N.A.A. (1997). Mycelia of Mucor rouxii as a source of chitin and chitosan. Food Chem., 60. 605-610.

26. Zheng, L.Y.; Zhu, J.F. (2003). Study on antimicrobial activity of chitosan with different molecular weights. Carbohyd. Polym., 54, 527-530. 